\title{
Mutasi EGFR pada Non-Small Cell Lung Cancer di Rumah Sakit Kanker "Dharmais"
}

\author{
LENNY SARI ${ }^{1}$, PURWANTO ${ }^{2}$ \\ 'Staf Medik Fungsional, Bagian Patologi Anatomi RS Kanker "Dharmais" \\ 2Staf Teknisi Bagian Patologi Anatomi RS Kanker "Dharmais"
}

Diterima: 16 September 2016; Direview: 25 Oktober 2016; Disetujui: 27 Oktober 2016

\section{KORESPONDENSI:}

dr. Lenny Sari, SpPA Staf Medik Fungsional Instalasi Patologi Anatomi RS. Kanker Dharmais email:oka802@gmail.com

\begin{abstract}
This descriptive study illustrated the proportion of EGFR mutation in non-small cell lung cancer (NSCLC) at "Dharmais" National Cancer Hospital. Examination of EGFR mutation started in 2015, 196 data was collected and 68 data being analyses. Fixed Formalin Paraffin Embedded (FFPE) processed by cobas $® 4800$ real time polymerase chain reaction. The results shown 34\% patients NSCLC with EGFR mutation and all of them was single mutation. EGFR mutation happens in Exon 21 L858R 10 cases (44\%), Exon 19del 12 cases (52\%) and the type of Exon 20 S768I 1 case (4\%). This study found a high proportion of EGFR mutation
\end{abstract}

Keyword: NSCLC, EGFR, Mutation

\begin{abstract}
ABSTRAK
Studi deskriptif ini menggambarkan proporsi mutasi Epidermal Growth Factor Receptor (EGFR) pada pasien dengan kanker paru di Rumah Sakit Kanker "Dharmais". Telah terkumpul 196 data, tetapi terdapat 68 data yang telah selesai dilakukan pemeriksaan mutasi EGFR. Mutasi EGFR diperiksa menggunakan Formalin-Fixed Paraffin-Embedded (FFPE) dengan teknologi cobas® 4800 real-time polymerase chain reaction. Ditemukan 34\% pasien dengan mutasi EGFR. Pada kelompok tersebut hanya ditemukan single mutation. Mutasi EGFR terjadi pada Exon 21 L858R sebanyak 10 kasus (44\%), Exon 19del 12 kasus (52\%), dan tipe Exon 20 S768I sebanyak 1 kasus (4\%). Studi ini masih berlangsung dan diharapkan dapat memberikan gambaran yang lebih komprehensif tentang mutasi EGFR pada kanker paru.
\end{abstract}

Kata Kunci: NSCLC, EGFR, Mutasi

\section{PENDAHULUAN}

I enis histopatologi yang paling banyak pada kanker paru adalah non-small cell lung cancer (NSCLC), mendekati 80-85\% dari seluruh kanker paru. ${ }^{1}$ Sebagian besar pasien telah stadium lanjut dan metastasis. ${ }^{2}$ Guideline untuk NSCLC merekomendasikan pemeriksaan mutasi Epidermal Growth Factor Receptor (EGFR). Hal ini sesuai untuk populasi Asia yang memiliki nilai prevalensi mutasi EGFR tinggi. ${ }^{3}$ Frekuensi mutasi EGFR pada orang Asia (Jepang) mendekati 30\%, lebih tinggi jika dibandingkan dengan populasi kulit putih yang sebesar 20\%. ${ }^{4,5,6}$ Mutasi EGFR lebih sering didapat pada wanita Asia dan tidak merokok. Dalam studi PIONEER yang merupakan studi prospektif tentang epidemiologi EGFR, khususnya pasien dari Asia (China, Hong Kong, India, Filipina, Taiwan, Thailand, dan Vietman), diperoleh frekuensi EGFR mutasi secara keseluruhan untuk populasi Asia sebesar 51,4\%. Data lain menunjukkan 
mutasi EGFR paling rendah adalah India $(22,2 \%)$. Angka ini mendekati frekuensi EGFR mutasi pada ras kulit putih. Secara berurutan, data EGFR mutasi untuk China 50,2\%; Hong Kong 47,2\%; Filipina 52,3\%; Taiwan 62,1\%; Thailand 53,8\%; dan Vietnam 64,2\%. Salah satu pertimbangan adanya EGFR mutasi dan respons terhadap EGFR-tirosin kinase yaitu berjenis kelamin perempuan, adenokarsinoma, tidak pernah merokok, dan ras Asia., ${ }^{7.8}$ Pemeriksaan EGFR merupakan salah satu cara untuk dapat memberikan terapi yang tepat terhadap pasien NSCLC. Namun, perlu diingat bahwa setiap obat tidak akan memberikan outcome yang sama pada setiap individu. Perlu dilakukan evaluasi pada exon berapa terjadi mutasi EGFR. Dengan demikian, pemberian terapi dapat dilakukan tepat guna. Di RS Kanker "Dharmais", pemeriksaan mutasi EGFR telah dilakukan mulai tahun 2015 sampai sekarang. Sebanyak 196 sampel telah terkumpul dan sedang dalam proses pemeriksaan mutasi EGFR. Laporan ini adalah sejarah pemeriksaan EGFR di RS Kanker "Dharmais" (RSKD). Oleh sebab itu, perlu diketahui seberapa besar mutasi EGFR pada pasien kanker paru di RS Kanker "Dharmais".

\section{MATERI DAN METODE}

Proses deteksi mutasi EGFR pada bahan pemeriksaan Formalin Fixed Paraffin Embedded Tissue (FFPET) menggunakan sistem teknologi cobas ${ }^{\circledR} 4800$ real- time polymerase chain reaction. Proses besar terbagi menjadi dua bagian, yaitu preparasi bahan pemeriksaan manual untuk mendapatkan deoxyribonucleic acid (DNA) dari FFPE dan amplifikasi deteksi dari DNA menggunakan menggunakan prinsip allele specific detection dengan cobas z 480 (Roche, Swiss). Persentase tumor minimal adalah 5\% dari keseluruhan bahan pemeriksaan. Kit yang digunakan adalah untuk preparasi bahan adalah cobas ${ }^{\circledR}$ DNA Sample Preparation Kit (P/N: 05985536190). Kit yang digunakan untuk amplifikasi dan deteksi mutasi adalah cobas ${ }^{\circledR}$ EGFR Mutation Test Kit (P/N: 06471463190).

Persiapan bahan pemeriksaan terbagi menjadi dua tahap dan sampel yang diterima berasal dari dua jenis spesimen, yaitu sitologi pulasan papanicolaou dan FFPE (Formalin Fixed Paraffin Embedded).

\section{Tahap I}

1. Sampel sitologi

Slide sitologi yang terpilih dan mengandung jumlah sel tumor yang mencukupi direndam dalam xylenes (Mallinckrodt, USA) sampai coverglass terlepas dengan sendirinya. Kemudian slide direndam dalam alkohol absolut (Mallinckrodt, USA) dan slide dikeringudarakan pada suhu ruang.

2. Deparafinisasi sampel FFPE

Proses deparafinisasi dan lisis bahan pemeriksaan FFPE pada slide dilakukan dengan merendam slide pada xylenes (Mallinckrodt, USA) dan Alcohol absolute (Mallinckrodt, USA). Setelah direndam dalam alcohol absolute, slide dikeringudarakan pada suhu ruang.

\section{Tahap II}

Jaringan pada FFPE atau sel pada slide sitologi kemudian dikerik menggunakan pisau bisturi BB520 (BBRAUN, Germany) dan dimasukkan ke dalam microsentrifuge tube $1 \mathrm{~mL}$ yang sebelumnya sudah berisi Tissue Lysis Buffer (TLB) dan Proteinase-K (PK). Selanjutnya, inkubasi pada suhu $56^{\circ} \mathrm{C}$ dan $90^{\circ} \mathrm{C}$, masing-masing selama 60 menit. Setelah proses ini selesai, harus dipastikan bahan pemeriksaan sudah terlarut dalam campuran TLB dan PK. Lakukan spinning untuk memastikan bahwa seluruh lisat yang tertinggal pada penutup microsentrifuge tube sudah turun ke dalam lisat.

\section{Isolasi DNA Genom}

Isolasi DNA dimulai dengan penambahan DNA Binding Buffer (DNA PBB) dan inkubasi selama 10 menit. Kemudian ditambahkan $100 \mu \mathrm{L}$ isopropanol (Merck, Germany ), dipastikan campuran homogen. Keseluruhan lisat, $550 \mu \mathrm{L}$, dimasukkan ke dalam filter tube dengan spinning column. Sentrifugasi (Hettich, Germany ) pada $8000 \mathrm{~g}$ selama 1 menit. Filter tube dipindahkan ke dalam spinning column baru dan dilakukan pencucian menggunakan Wash Buffer I (WBI) dan Wash Buffer II (WB2), masing-masing disentrifugasi pada 8000 g selama 1 menit. Kemudian dilakukan pengeringan filter membran dengan sentrifugasi pada 16000-18000 g selama 1 menit. Elusi DNA dilakukan dengan menambahkan $100 \mu \mathrm{L}$ Elution Buffer (EB) di bagian atas tengah membran filter. Kemudian sentrifugasi pada $8000 \mathrm{~g}$ selama 1 menit.

\section{Pengukuran dan Kuantifikasi DNA Genom}

Pengukuran dan kuantifikasi DNA Genom dilakukan segera setelah proses isolasi selesai menggunakan Nanodrop UV-Vis Spectrophotometer (ND-2000). Blanko yang digunakan adalah larutan EB. Jumlah minimal konsentrasi adalah $5 \mathrm{ng} / \mathrm{\mu L}$. Dibutuhkan 2 kali pembacaan nilai yang konsisten untuk verifikasi pengukuran. 


\section{Persiapan Real Time PCR untuk Deteksi EGFR}

Area kerja persiapan Real Time PCR terpisah dengan area kerja isolasi sampel DNA genomik dengan tujuan menghindari kontaminasi. Persiapan proses RT PCR terbagi menjadi dua proses, yaitu persiapan sampel dan persiapan mastermix (MMX). Konsentrasi DNA genomik yang digunakan dalam MMX adalah $2 \mathrm{ng} / \mu \mathrm{L}$ sebanyak $25 \mu \mathrm{L}$. Pelarutan DNA genomik hingga mencapai konsentrasi 2 ng/ $\mu \mathrm{L}$ dapat menggunakan larutan DNA Sample Diluent (SD). Microsentrifuge tube harus divorteks sebelum dan sesudah pelarutan.Untuk persiapan larutan kerja MMX, harus dipastikan area kerja sudah dibersihkan dengan alkohol 70\% dan operator sudah menggunakan sarung tangan sebelum dan sesudah membersihkan area kerja. Volume total larutan kerja MMX adalah $25 \mu \mathrm{L}$. Dengan hati- hati, ditambahkan $25 \mu \mathrm{L}$ larutan kerja MMX 1, 2, dan 3 ke dalam lubang atau well Amplification Detection (AD) plate sesuai dengan jumlah sampel yang dikerjakan. Kemudian pada lubang A01, A02, dan A03 ditambahkan Mutant Control (MC), sedangkan untuk lubang B01, B02, dan B03 ditambahkan Negative Control (NC). Volume DNA sampel dan kontrol masing-masing adalah 25 $\mu \mathrm{L}$ untuk setiap lubang dan setiap MMX. Resuspensi 2 kali setiap penambahan DNA sampel maupun kontrol untuk memastikan homogenisasi. Resuspensi dilakukan dengan hati-hati untuk menghindari gelembung yang dapat megganggu proses deteksi RT PCR. Tahap terakhir adalah proses sealing $A D$ plate dengan sealing film.

\section{Deteksi Mutasi EGFR Dengan Cobas z 480}

Deteksi mutasi EGFR menggunakan primer komplementer dan probe oligunukletida terlabel dengan pewarna fluoresens. Cobas ${ }^{\circledR}$ EGFR test digunakan untuk mendeteksi mutasi sebagai berikut (1) Exon 18: G719X (G719A, G719C, and G719S); (2) Exon 19: delesi dan mutasi kompleks; (3) Exon 20: S768I, T790M, dan insersi; (4) Exon 21: L858R. Deteksi menggunakan cobas z 480 dimulai dengan memasukkan ID sampel dan lot number kit yang digunakan pada software. Kemudian AD plate yang sudah berisi sampel dimasukkan untuk memulai proses amplifikasi dan deteksi. Kontrol mutan dan negatif kontrol digunakan untuk validasi hasil running.

\section{HASIL}

Penelitian dilakukan sejak Juli 2015 sampai dengan Juni 2016. Pengambilan data dimulai pada bulan Maret sampai Juni 2016 di Instalasi Patologi
Anatomi, RS Kanker "Dharmais". Subjek pada penelitian ini adalah pasien yang telah secara histologi dinyatakan positif kanker paru. Dari total sampel sebesar 196, diperoleh sampel laki-laki sebanyak 130 orang (66\%) dan perempuan 66 orang (34\%) (diagram 1). Jumlah kasus yang terdeteksi mutasi EGFR sebanyak 71/196 (36\%), wild type sebesar 106/196 (54\%), dan invalid sebesar 19/196 (10\%). Dari 71 kasus yang terdeteksi mutasi EGFR diperoleh jenis mutasi tunggal dan kombinasi. Tipe mutasi tunggal yang teridentifikasi ada 4 jenis, yaitu Exon 21 L858R sebesar 39\%, Exon 19del sebesar 39\%, Exon 20 ins 20\%, dan tipe Exon 20 S7681 1\%. Sedangkan tipe kombinasi yang ditemukan yaitu Exon 21 L858R \& Exon 20 T790M sebesar 22\%, Exon 19 del $\&$ Exon 20 insertion sebesar 33\%, Exon 21 L858R \& Exon 20 insertion $11 \%$, Exon 18 G719X \& Exon 20 insertion $11 \%$, serta Exon 19 del $\&$ Exon 20 T790M sebesar 22\%.

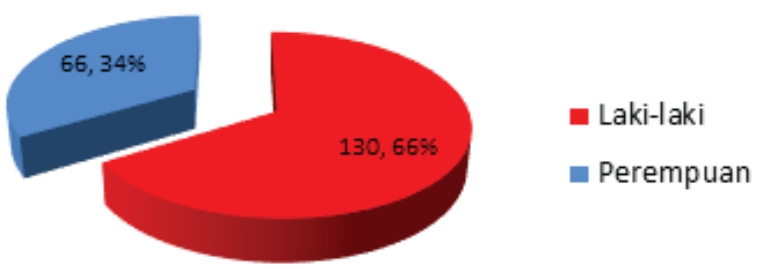

Diagram 1: Sebaran pasien kanker paru berdasarkan jenis kelamin

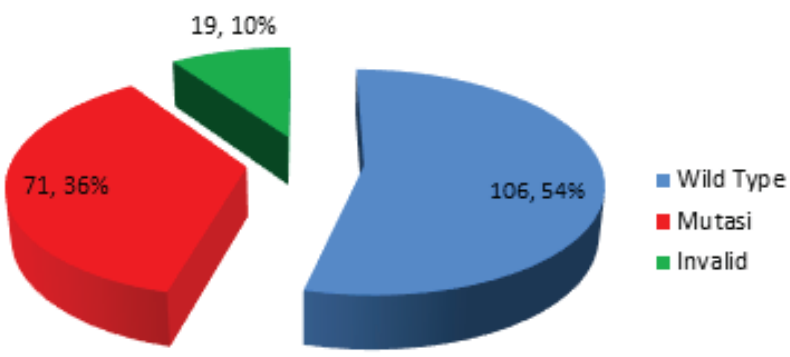

Diagram 2: Persentase kasus mutasi EGFR ( $\mathrm{N}=196$ sampel)

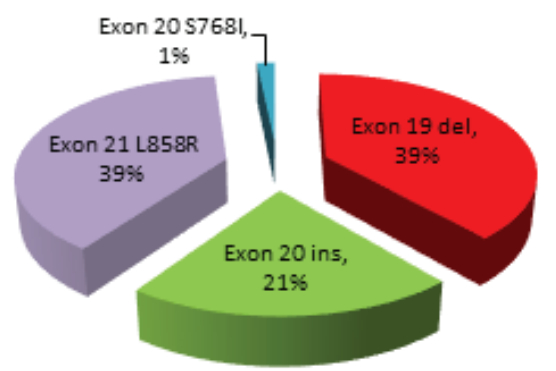

Diagram 3: Persentase Single Mutation EGFR ( $\mathrm{N}=196$ sampel) 

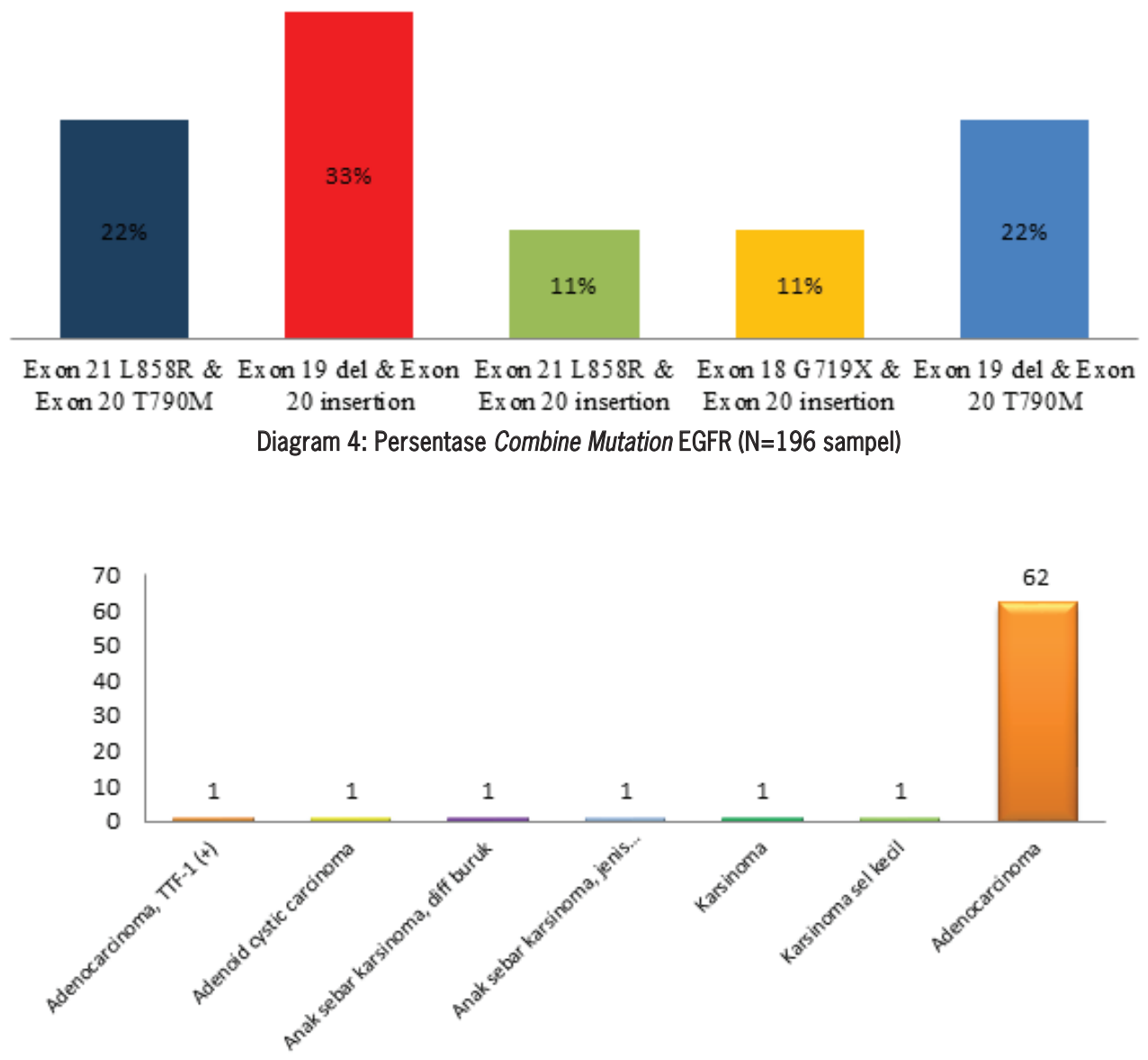

Diagram 5: Gambaran histologi kanker paru di RS Kanker "Dharmais" yang diperiksa mutasi

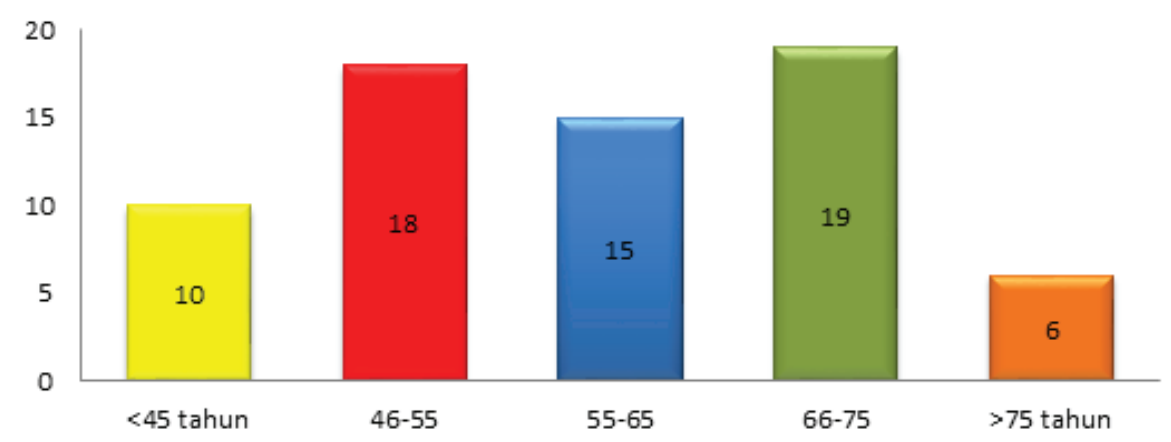

Diagram 6: Gambaran usia pasien kanker paru di RS Kanker "Dharmais" yang diperiksa mutasi 
Setelah dilakukan kelengkapan data, diperoleh 68/196 kasus (34,6\%) yang memiliki data lengkap. Berdasarkan jenis histologinya diperoleh 7 jenis histologi dan didominasi dengan adenokarsinoma 91,1\% (62/68). Sedangkan tipe histologi yang lain masing-masing karsinoma, karsinoma sel kecil, adenokarsinoma TTF-1(+), adenoid cyctic karsinoma, anak sebar karsinoma, anak sebar karsinoma masingmasing memiliki 1 kasus (1,4\%) (Diagram 5).

Gambaran usia kanker paru pada laporan ini adalah 33-86 tahun, dengan rata-rata 59 tahun. Frekuensi paling banyak berada pada rentang 66-75 tahun, yaitu 19 kasus (28\%). Setelahnya adalah rentang 46-55 tahun 18 kasus (26\%) dan 55-65 tahun sebanyak 15 kasus (22\%). Pasien yang berusia lanjut $>7$ tahun berjumlah 6 kasus (9\%).

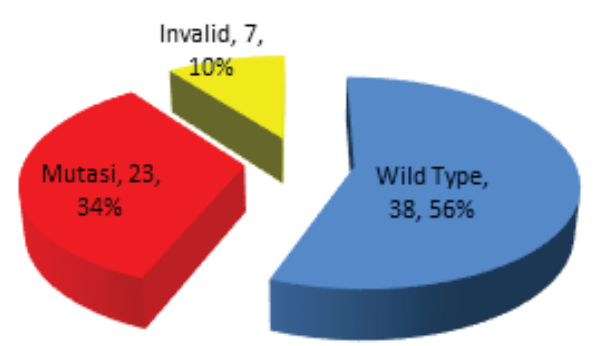

Diagram 7: Gambaran mutasi pasien kanker paru

Berdasarkan diagram 7 diperoleh gambaran bahwa yang bermutasi sebanyak 23 kasus (34\%), 38 kasus wild type (56\%), dan invalid sebanyak 7 kasus (10\%).

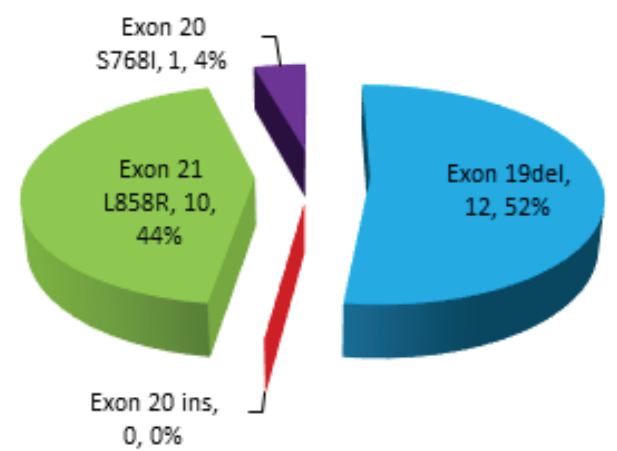

Diagram 8: Gambaran jenis mutasi single kanker paru

Pada laporan ini, dapat diperoleh gambaran bahwa pasien tipe mutasi yang ada adalah mutasi tunggal (single mutation). Terdapat 4 jenis mutasi pada keseluruhan sampel, tetapi hanya 3 jenis yang muncul pada sampel ini, yaitu Exon 21 L858R sebanyak 10 kasus (44\%), Exon 19del sebanyak 12 kasus (52\%), dan tipe Exon 20 S768I sebanyak 1 kasus (4\%)

\section{PEMBAHASAN}

Pasien kanker paru memiliki prognosis yang buruk bila terdeteksi pada stadium lanjut. Di RS Kanker "Dharmais", Bagian Patologi Anatomi telah melakukan pemeriksaan mutasi EGFR terhadap 68 sampel dengan tujuan mengetahui proporsi jumlah pasien kanker paru dengan mutasi EGFR.

Temuan pada penelitian ini menunjukkan bahwa pasien dengan jenis kelamin laki-laki, rerata usia 59 tahun, dan jenis histopatologi adenokarsinoma. Hal ini cenderung berbeda dengan temuan dalam studi PIONEER yang menggambarkan bahwa pasien berjenis kelamin perempuan memiliki kemungkinan lebih besar untuk mutasi EGFR. Selain itu, disebutkan juga bahwa pasien yang tidak merokok dan beretnis Asia, berisiko lebih tinggi untuk mendapatkan mutasi EGFR. $^{7}$

Proporsi pasien dengan mutasi EGFR sebesar 34\%. Angka ini cukup tinggi mengingat dalam beberapa studi disebutkan bahwa proporsi mutasi EGFR pada kulit putih sebesar 20\%. Namun demikian, studi-studi di wilayah Asia menyebutkan bahwa proporsi mutasi EGFR lebih dari 20\%. Di Korea, misalnya, disebutkan bahwa dari total 36,3\% yang mutasi EGFR didominasi oleh adenokarsinoma, yaitu 39\%, dan KSS 11,1\%. Di China 50,2\%; Hong Kong 47,2\%; Filipina 52,3\%; Taiwan 62,1\%; Thailand 53,8\%; dan Vietnam 64,2\%. ${ }^{6}$ Hal ini menunjukkan bahwa untuk negara-negara di Asia, risiko mutasi EGFR pada kanker paru lebih tinggi dibandingkan pada kasus-kasus kaukasian. ${ }^{8-10}$

Titik mutasi EGFR pada temuan ini didominasi pada rentang exon 19-21." Mutasi yang paling banyak hampir sama dengan temuan pada penelitian lain, yaitu di antara exon 18-21. Tipe mutasi yang paling banyak yaitu exon 19del. Di Korea tipe mutasi ini memiliki nilai yang lebih kecil dibandingkan dengan mutasi Exon 21 L858R.

\section{KESIMPULAN}

Diperoleh angka mutasi EGFR pada kasus NCSLC sebesar 34\%, dengan tipe single mutation Exon 21 L858R sebanyak 10 kasus (44\%), Exon 19del 12 kasus (52\%), dan tipe Exon 20 S768I sebanyak 1 kasus (4\%). Masih diperlukan analisis lanjutan untuk memperoleh data yang lebih pasti dan mewakili populasi. 


\section{DAFTAR PUSTAKA}

1. D'Addario G, Früh M, Reck M, Baumann P, Klepetko W, Felip E;ESMO Guidelines Working Group. Metastatic non-small-cell lung cancer: ESMO Clinical Practice Guidelines for diagnosis, treatment and follow-up. Ann Oncol. 2010;21(Suppl 5):v116v119.

2. Crinò L, Weder W, van Meerbeeck J, Felip E; ESMO Guidelines Working Group. Early stage and locally advanced (nonmetastatic) non-small-cell lung cancer: ESMO Clinical Practice Guidelines for diagnosis, treatment and follow-up. Ann Oncol. 2010;21(Suppl 5):v103-v115.

3. Choi YL, Sun JM, Cho J, Rampai S, Han J, Parasuraman S et.al. EGFR mutation testing in patients with advance nonsmall cell lung cancer: A comprehensive evaluation of real world practice in an East Asian tertiary hospital. PloseOne. Vol 8 (2), Feb 2012.

4. Kawaguchi T, Matsumura A, Fukai S, et al. Japanese ethnicity compared with Caucasian ethnicity and never-smoking status are independent favorable prognostic factors for overall survival in non-small cell lung cancer: a collaborative epidemiologic study of the National Hospital Organization Study Group for Lung Cancer (NHSGLC) in Japan and a Southern California Regional Cancer Registry databases. I Thorac Oncol. 2010; 5:1001-1010.

5. D'Angelo SP, Pietanza MC, Johnson ML, et al. Incidence of EGFR exon 19 deletions and L858R in tumor specimens from men and cigarette smokers with lung adenocarcinomas. J Clin Oncol. 2011;29:2066-2070.
6. Rosell R, Moran T, Queralt C, et al; Spanish Lung Cancer Group.Screening for epidermal growth factor receptor mutations in lung cancer. N Engl J Med. 2009;361:958-967.

7. Shi Y, Siu-Kie J, Thongprasert S, Srinivasan S, Tsai C-M, Khoa M T, Heeroma K et.al. A Prospective, Molecular Epidemiology Study of EGFR Mutations in Asian Patients with Advanced Non Small-Cell Lung Cancer of Adenocarcinoma Histology (PIONEER). Journal of Thoracic Oncology. 2014;9(2): Feb 2014.

8. Shigematsu H, Lin L, Takahashi T, et al. Clinical and biological features associated with epidermal growth factor receptor gene mutations in lung cancers. J Natl Cancer Inst. 2005;97:339346.

9. Mitsudomi T, Kosaka T, Endoh $\mathrm{H}$, et al. Mutations of the epidermal growth factor receptor gene predicts prolonged survival after gefitinib treatment in patients with non-smallcell lung cancer with postoperative recurrence. J Clin Oncol. 2005;23:2513-2520.

10. Saijo N, Takeuchi M, Kunitoh H. Reasons for response differences seen in the V15-32, INTEREST and IPASS trials. Nat Rev Clin Oncol. 2009;6:287-294.

11. Eberhard DA, Johnson BE, Amler LC, et al. Mutations in the epidermal growth factor receptor and in KRAS are predictive and prognostic indicators in patients with non-small-cell lung cancer treated with chemotherapy alone and in combination with erlotinib. J Clin Oncol. 2005;23:5900-5909. 